\title{
Factors of development of children's sports schools in rural areas
}

\author{
Maksim Kocheryan, Irina Vashlyaeva, and Tatiana Volovik \\ Ural State University of Economics, 620144, 8 Marta Str, 62, Ekaterinburg, Russia
}

\begin{abstract}
The article presents an analysis of the external and internal environment of children's sports schools in rural areas in the form of a SWOT matrix. Children's sports schools in rural areas are distinguished by a huge set of sports disciplines, many their own facilities and a low pricing policy. Among the most significant disadvantages are the lack of active promotion of schools and a small percentage of paid services compared to budget ones. To improve the situation of children's sports schools in rural areas, it is proposed to create a promotion program that will help increase the number of students and affect the growth of the organization's income.
\end{abstract}

\section{Introduction}

Sports organization a legal entity, regardless of its organizational and legal form, carrying out activities in the field of physical culture and sports as the main activity. The market for physical education and sports in the Russian Federation is mainly represented by state and municipal organizations. The goal of the effective management of the state physical education and sports organization is a constant desire to meet the needs and sports interests of various categories of the population in physical education and sports services. This goal is only possible based on a comprehensive assessment of customer satisfaction.

One of the types of physical education and sports organizations are children's sports schools. Such organizations are municipal budgetary educational institutions whose main goal is the implementation of educational activities on additional general educational programs for children under 18 years of age and the implementation of services in the interests of the individual, society, and the state.

Children's sports schools are non-profit sports organizations since the purpose of their activities is not to make a profit. At the same time, non-profit organizations can carry out business activities, but only to achieve the goals for which they were created. As noted in the works [1-3], activities in the field of physical culture are considered in the concept of social marketing, which requires considering the interests of consumers on the one hand, and the interests of society on the other [4,5]. This means that customer needs come to the fore, as well as social indicators and the associated pedagogical effect. In the marketing of sports services Kahle [6] and Ferrand [7], the main criterion should be end-user inquiries [8]. Accordingly, the authors Shannon [9] and Roy [10] propose the use of a wide range of analytical tools survey methods. 


\section{Methodology}

The research methodology includes the combination of survey technology and SWOTanalysis for the formation of solutions in the management of the municipal sports organization.

As part of an independent quality assessment, in September-October 2021, a survey was conducted of citizens - recipients of services in the field of physical culture and sports. A total of 119 people were interviewed. Respondents were adult beneficiaries or parents of minors. The respondents' data is shown in Figure 1.

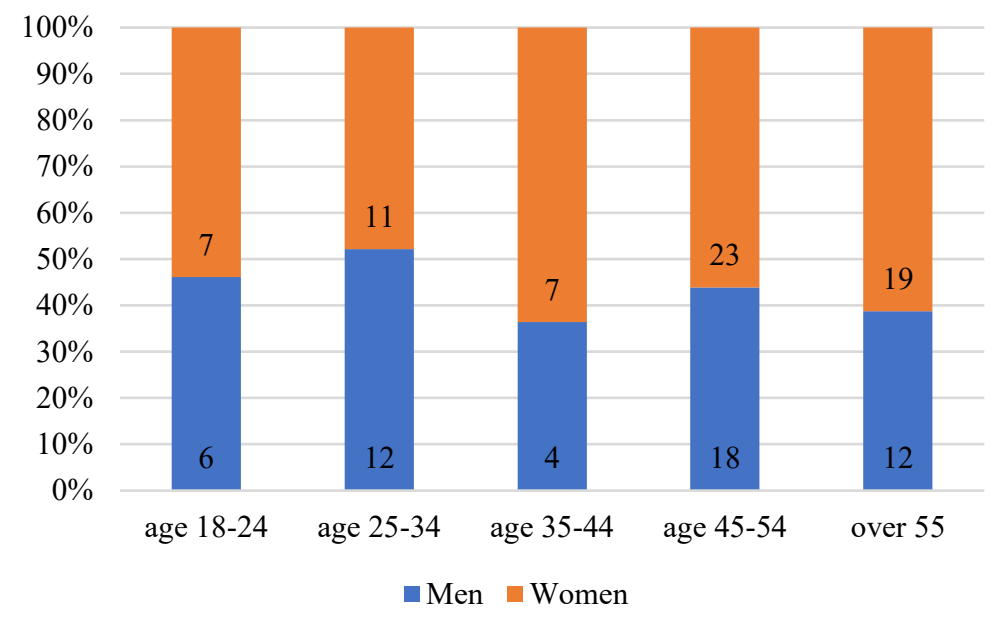

Fig. 1. Database of survey respondents

After assessing the quality of services by questionnaire methods, a generalization of the factors of a municipal sports organization's activities was carried out based on an analysis of its internal and external environment, including a strategic analysis of activities, a SWOT analysis and competitiveness analysis using a competitiveness polygon.

As a rule, the analysis considers the following factors of the internal environment that affect the activities of a children's sports school: organizational structure, sources of funding for activities, material, and technical base, labour resources, scientific and information resources. The external factors affecting the activities of municipal sports organizations include: the number of municipal subsidies, sports legislation, taxes, the economic situation in the country, the transfer of property rights to property and so on.

Figures and tables, as originals of good quality and well contrasted, are to be in their final form, ready for reproduction, pasted in the appropriate place in the text. Try to ensure that the size of the text in your figures is approximately the same size as the main text (10 point). Try to ensure that lines are no thinner than 0.25 point.

\section{Results and Discussion}

Next, we present the results of the study. Table 1 presents the results of a survey of recipients of municipal services in children's sports schools in rural areas. 
Table 1. Quality assessment of the services provision in children's sports schools in rural areas, $\%$

\begin{tabular}{|c|c|c|c|c|}
\hline \multirow{2}{*}{ Quality indicators } & \multicolumn{4}{|c|}{ Evaluation of the quality of services in \% } \\
\cline { 2 - 5 } & Satisfied & $\begin{array}{c}\text { Partially } \\
\text { satisfied }\end{array}$ & $\begin{array}{c}\text { Not } \\
\text { satisfied }\end{array}$ & $\begin{array}{c}\text { Difficult } \\
\text { to answer }\end{array}$ \\
\hline Building condition (premises) & 68,3 & 27,5 & 4,2 & - \\
\hline $\begin{array}{c}\text { Inventory status } \\
\text { The ability to get background information } \\
\text { about the services provided }\end{array}$ & 89,4 & 10,6 & - & - \\
\hline $\begin{array}{c}\text { Satisfaction with personal interaction with the } \\
\text { coaching staff }\end{array}$ & 55,2 & 36,1 & 8,5 & 3,2 \\
\hline $\begin{array}{c}\text { Service waiting conditions (conditions of } \\
\text { waiting for children until the end of classes in } \\
\text { the parents section) }\end{array}$ & 55,7 & 34 & 10,6 & - \\
\hline Satisfaction with the opening hours & 89,4 & 4,2 & 6,4 & - \\
\hline Satisfaction with employee competence & 89,4 & 0 & 4,2 & 6,4 \\
\hline $\begin{array}{c}\text { To what extent are you satisfied with the } \\
\text { activity of the children's sports school? }\end{array}$ & 59,6 & 23,4 & - & 17 \\
\hline
\end{tabular}

As can be seen from the table, most consumers are satisfied with the activities of the municipal sports organization, however, it is necessary to note the partial satisfaction of consumers with personal interaction with the coaching staff and the opportunity to get background information about the services provided. These service parameters need to be improved.

According to the results of the analysis was formed a generalized matrix of the SWOTanalysis, presented in Table 2.

Table 2. The matrix of SWOT analysis of the activities of sports schools in rural areas

\begin{tabular}{|c|c|}
\hline Strengths & Weaknesses \\
\hline $\begin{array}{l}\text { 1. High qualification of the teaching staff } \\
\text { 2. Minor staff turnover } \\
\text { 3. The high level of quality of budget services } \\
\text { 4. Low pricing policy } \\
\text { 5. A large number of sports departments } \\
\text { 6. A large number of infrastructure in fairly } \\
\text { good condition } \\
\text { 7. A large number of athletes studying on a } \\
\text { budgetary basis } \\
\text { 8. Good reputation due to the large number of } \\
\text { athletes who have won various titles }\end{array}$ & $\begin{array}{l}\text { 1. Lack of time for the implementation of paid } \\
\text { services } \\
\text { 2. Low income from paid activity } \\
\text { 3. Dependence on state authorities } \\
\text { 4. Sports facilities are located in different } \\
\text { places } \\
\text { 5. Incomplete and sometimes untimely } \\
\text { provision of equipment, inventory and outfit } \\
\text { 6. The lack of own accounting (only central in } \\
\text { the Office of Sports of the Sverdlovsk region) } \\
\text { 7. Poor development of scientific and } \\
\text { information resources, incl. advertising } \\
\text { 8. The lack of young and promising coaches }\end{array}$ \\
\hline Opportunities & Threats \\
\hline $\begin{array}{l}\text { 1. State policy in the field of physical culture } \\
\text { and sports will attract more people } \\
\text { 2. Changes in the legislation of the Russian } \\
\text { Federation, which will have a positive impact } \\
\text { on municipal educational institutions } \\
\text { 3. Transfer to use and management of a new } \\
\text { high-tech sports facility } \\
\text { 4. Attracting new consumer groups (people } \\
\text { with disabilities) } \\
\text { 5. The introduction of innovative educational } \\
\text { technologies and changing the usual system of } \\
\text { training } \\
\text { 6. The emergence of new paid services }\end{array}$ & $\begin{array}{l}\text { 1. Reduction or invariance of the amount of } \\
\text { municipal subsidies from the budget of the } \\
\text { Sverdlovsk region } \\
\text { 2. Inflation } \\
\text { 3. The increase in the volume of municipal } \\
\text { tasks } \\
\text { 4. The emergence of new taxes and an increase } \\
\text { in tax rates } \\
\text { 5. The increase in the cost of utility payments; } \\
\text { 6. Reducing the standard of living of the } \\
\text { population }\end{array}$ \\
\hline
\end{tabular}


Children's sports schools in rural areas are distinguished by a huge set of sports disciplines, many their own facilities and a low pricing policy. Among the most significant shortcomings can be called the lack of active promotion of the school and a small percentage of paid services compared with the budget.

As for the external environment of the organization, the Russian economy is in an unstable state, so the incomes of the population are falling and the municipal budget also does not increase, which significantly affects the number of people involved in sports. In addition, the state policy now cannot be called favorable for the activities of such organizations, since new taxes constantly appear and utility payments increase, which occupy a significant part of expenses. However, currently, the state is actively creating strategic programs for the development and support of sports in the Russian Federation. Consequently, soon may be followed by favorable changes in sports legislation and in the system of training athletes.

\section{Conclusion}

Thus, because of the conducted research, the strengths, and weaknesses of the development of children's sports schools in rural areas were identified. The most vulnerable point is the lack of an effective promotion strategy, a strong link in comparison with competitors is the range of services and the price for them.

To improve the situation of children's sports schools in rural areas, it is proposed to create a promotion program that will help increase the number of students and affect the growth of the organization's income. Considering that the number of Internet users is growing every day, it will be effective to place your ads on various portals, forums, sites, on those where people read the news, because these sites are usually the most visited, as well as to actively develop pages in social networks such as Vkontakte and Instagram.

\section{References}

1. A. Buhler, G. Nufer Relationship marketing in sports (2012)

2. J. Burnett, A. Menon, D. T. Smart, Journal of Advertising Research, 33, 5 (1993)

3. J. H. Donnelly, W. George How consumers evaluation processes differ between goods and services (1981)

4. S. B. G. Eysenck, D. H. Saklofske, Canadian Journal of Behavioural Science/Revue canadienne des sciences du comportement, 15, 2 (1983)

5. G.R. Foxall, Journal of Marketing Management, 8, 4, (1992)

6. L.R. Kahle, C. Riley. Sports marketing and the psychology of marketing communication (2004)

7. A. Ferrand, S. McCarthy, Marketing the sports organisation: Building networks and relationships (2008).

8. M. Mitre, P. Ordóñez de Pablos, International Journal of Sport Management and Marketing, 5,3 (2009)

9. J. R. Shannon, Journal of services marketing, 13, 6 (1999)

10. D.P. Roy, T.R. Graeff, Sport Marketing Quarterly, 12, 3 (2003) 